\author{
Jakub Gortat
}

\title{
GERMAN AND EUROPEAN EXPERIENCES IN DEVELOPING NATIONAL IDENTITY AND PATRIOTISM - SHEER RESEMBLANCES OR MUTUAL INSPIRATIONS?
}

The problem of a common European identity and a group of values that are recognizable for the whole European community seems nowadays to be a more current topic than ever before. The European Union has become a highly developed bureaucratic community, with special tools to conduct foreign policy in the most rudimentary questions. It has been strengthened by the reforming treaty of Lisbon which came into force in 2009 and rendered it a widely respected organization. The questions of a European identity, however, have grown larger in the public discourse and appear to express the necessity of confirming a group of shared interests and values. The question arises whether this European identity is a concept held only by the leading European politicians and bureaucrats; also by the societies of the member states; or whether it is solely an abstract idea that cannot be put into practice, especially considering the fact that many European states still encounter obstacles in defining their own identity.

The best example for illustrating the process would seem to be the German experience of constructing a national identity after the end of World War II. There are many distinct aspects that show a resemblance between the development of German identity and the same issue and process with respect to the European Community. This article aims to enumerate and discuss these similarities. It is also an attempt to answer some of the essential questions that pertain to the nature of forming a national identity, such as confrontation with the past in the contemporary discourse, in both the German and European contexts, or the degree of homogenization of the societies. The first part of the article mainly concentrates on the problem of the German identity and will emphasize its uniqueness against a background of the vast majority of other European countries. Thereafter, the attention is focused on the same phenomena in the European discourse, highlighting the evident resemblances between the two debates. 


\section{German national identity after 1945 - a short overview}

Having regard to almost all the countries discussed in this chapter, one term is exceptionally often stressed in the literature on the topic of national identity-the founding myth, which may be a ritual or founding of a city, a group presented as genealogical ancestors, the founding fathers of a nation, or a narrative based on a belief, an idea or a philosophy of great relevance to the future development of the community. In this context the Federal Republic of Germany appears as an unusual country, whose national identity was not determined by any founding myths, especially after the end of World War II when the official and prevailing ideology turned out to be a source of atrocities previously unknown in the civilized world. The de-nazification and re-education processes imposed upon German society in 1945 were aimed at proving how contorted and evil the Nazi ideology had been, and implementing new rules, political models and values, which from that time forth were supposed to mould the social life in the just-defeated country. Moreover, the shame of what had been done during the Nazi period and the common repudiation of the truth unveiled after the liberation of concentration camps contributed to the collapse of the point of reference in the discussion of the problem of identity. Any factors that could have made Germans take pride in belonging to German nation had to be aside and seemed inappropriate after having discovered the scale of the war crimes. Instead of a founding myth typical for many other countries, in the Federal Republic of Germany there can be observed various factors that predestined the construction of a new, modern national identity. On the other hand, the second German state, i.e., the German Democratic Republic, is an example of a country with a founding myth that was harmonized shortly after the end of World War II and promptly began to function in the official discourse. The socialist republic was supposed to be an antifascist and anti-imperialist bulwark that had assertively come to terms with its Nazi past, whereas its Western neighbour was perceived as a society deliberately neglecting this process.

Despite the lack of a founding myth in the Federal Republic of Germany (FRG), there were some factors that acted as narratives in determining the national identity of the country. The first factor can be described as a victims' discourse, in German terminology defined as 'Opfernarrative' (narratives of the victims). It stemmed directly from the tremendous defeat Germany suffered in 1945, which precipitated the country into division, territorial losses, hunger, homelessness and forced migrations. The horrifying air raids conducted by the allied armies left hundreds of German cities and towns in ruins. Many industrial facilities were reduced to rubble and the obligatory shift from a wartime to a peacetime economy laid bare the deplorable economic situation. Millions of refugees who streamed in from the lost Eastern territories of the Reich needed to find accommodations 
and integrate with the Western part of German society. The imprisonment of millions of men, mostly in the Soviet Union, many of whom would not be released until the 1950s, inevitably led to a demographic crisis.

At the same time, however, the calamities of 1945 marked a new beginning, the so-called 'Zero Hour' ('Stunde Null'), when Germany turned over a new leaf in its existence. Buildings had to be rebuilt, whole cities had to be reconstructed and apathy had to be managed and overcome. Very quickly the feeling of desolation was replaced by a zeal for work and a determination to survive despite any hardship. By facing these hardships German society gradually, albeit still in a short period of time, developed a common consciousness that made only a certain group of Third Reich politicians and military commanders responsible for the war and atrocities. In this view, ordinary Germans were involuntarily involved in the war and needed to suffer because of Hitler and his closest comrades. This impression was additionally enforced by the course of the Nuremberg trials, where only the most outstanding politicians and military leaders had been convicted, and also by the inconsequential re-education which - despite spreading to all the layers of the society - turned out to be quite superficial and was soon aborted. The abolitionary politics of Konrad Adenauer's government in the 1950s bestowed upon the Germans a conviction of their innocence and/or the insignificance of their past as well.

The 'victims' narratives' had their roots in both the political discourse and the cultural trends or models in the early years of the FRG. This can be seen, above all, in the activities of the Federal Ministry for Displaced Persons, Refugees and War Victims, which was established in 1949. The Ministry represented many, many victims throughout all the years until 1969, when it was dissolved. It contested the existence of Oder-Neisse-border and endeavoured to regain the former Eastern territories, which in turn permanently hindered German relations with Poland and the Czechoslovakian Republic. Research was also carried out focusing on German losses during the war, and its results were published, beginning in 1958 until the 1960s, in five volumes entitled 'Documents of German War Losses' ('Dokumente deutscher Kriegsschäden'). These works presented the losses in statistical terms, but also included relations of eye witnesses to the destruction of the country. However, the most manifest trails of commemoration of the air raid victims (and expellees) were and are to be found at the local level, where the anniversaries of air attacks were highlighted in the press releases, together with accounts, for example, of the speeches of the town mayors ${ }^{1}$. Moreover, many of the inflicted towns and cities soon had monuments, commemorative plaques or other memorials that honoured the local victims of bombardments.

${ }^{1}$ See: J. Arnold, D. Süß, M. Thiessen (red.), Luftkrieg. Erinnerungen in Deutschland und Europa, Wallstein Verlag, Göttingen 2009. 
What's more, the speeches of the officials often highlighted the sacrifices of local people and their willingness to rebuild the buildings, and questioned the sense of legitimacy of the allied air raids.

Another political issue that can be found in the public victims' discourse was the problem of repatriation of the so-called 'Prisoners of War' from the Soviet Union. The fact that their number was unknown and unconfirmed by the Soviet side led to public outcry, exerting pressure on Adenauer's government. The Chancellor's visit to Moscow in 1955 enabled about 10,000 former German soldiers to return from the prison camps in Russia, and upon their return they were then greeted publically as war heroes.

The fate of the expellees, PoWs and victims of the air war, brought up frequently in the political discourse, was reflected in the early German culture after 1945. All three issues became significant themes in literature, but most of all in cinematography. Two typical trends in German movies were born shortly after the war. The first one emerged in 1946 and lasted until 1949 in all occupation zones - the so-called 'rubble films' ('Trümmerfilme') - which had their plot in bombarded cities and presented different aspects of the damaged lives of their dwellers. Another movie trend that gained popularity in the 1950s was called 'Homeland films' ('Heimatfilme'). The action of these movies usually took place in small towns or cottages, whose inhabitants often reminisced sadly about the lost homeland and the unattainable values and lifestyles intertwined with it. Later, the theme of a soldier's suffering became commonplace in some of the works produced, beginning in the late 1950s. Their main character is an ordinary soldier confronted with strong-minded officers, susceptible to feelings of remorse over the killings, as well as to proving their masculinity and courage. The inflicted wounds, both mental and physical, make them incapable of coping with the horror of war and expose their extent of their sacrifices in an unjust war.

Victims other than German ones were either marginalized or barely noticeable in the public and cultural memory. The first work that could be characterized as a breakthrough was Anne Frank's diary, first published in the Netherlands in 1947, then in 1950 in France and Germany, where it became a great success. Anne Frank was quickly identified as a cultural figure who represented the destruction of youth and the holocaust, and her diary turned into one of the most famous and notable works of literature illustrating the atrocity of the holocaust. However, the most significant breakthrough in German memory took place in the 1960s. The trial of the SS concentration camp staff in Ulm in 1958, followed by the Eichmann trial in Jerusalem in 1961, and finally the Auschwitz Trials in Frankfurt between 1963 and 1968, provoked a wide public debate about German responsibility for the Nazi terror and foreshadowed a significant change in the attitudes of youth towards their parents' generation, which came to be perceived as a generation of bystanders who did not demur to Nazi policies and atrocities. The student protests that dominated German developments in the late 1960s, even though 
they had serious negative ramifications in the form of extreme-left terrorist actions, drew public attention from German victims to the victims of the Germans and opened a new chapter in forming FRG's national identity.

The commemoration of German victims in the early years of the FRG does not mean that other groups of victims were utterly omitted in the discourse and the issue of crimes was obliterated. Many intellectuals did appeal for weighing up the question of responsibility more thoroughly and in a more complex manner. At this point Karl Jaspers should be mentioned, whose work 'Question of guilt' ('Die Schuldfrage ${ }^{2}$ ') discusses the issue of collective responsibility and is based, to some extent, on the modern collective memory theory proposed by Maurice Halbwachs. ${ }^{3}$ Another intellectual who made an attempt to answer the question of German culpability was Theodor Adorno, who is well known for his statement that 'after Auschwitz no poem should be written'. Nonetheless, their voices usually remained unnoticed in the 1950s, as the society's efforts were first concentrated on rebuilding the cities and then on enjoying the effects of the 'economic wonder' and a consumer lifestyle.

Another important inducement leading to the escape from the past and to the construction of a new identity was the German constitution. The path to its promulgation symbolizes the entire process of democratizing Germany, as the most solemn and essential rules that were supposed to form the new political order derived only partially from Germans. Its origins are to be found in the discord between the former allied powers that began shortly after the end of the world war. The paralysis of the Allied Control Council, which became evident in 1946, commenced an entire process that led to the creation of a new German state from the Western occupation zones, one that would gradually obtain independence under strict allied control. The first step in this process was restoration of the system of political parties and the elections to Landstags, i.e. local administration bodies. Parliaments of the particular federal states adopted their own constitutions and formed structures of a federal political system. Meanwhile, the former Western zones were converted into one political organism - first in 1946 with the combining of the American and the British zones, next in 1947 into a Trizone, also combining the French zone. After the Berlin crisis in 1948-1949, the signing of a peace treaty, as provided for in the Potsdam Conference Act, became undeniably impossible. Lengthy negotiations over the shape of the future constitution were launched in London in February 1948 with attendance of the three Western powers and the Benelux countries. The final act of the conference, the so-called the 'London Recommendations', was passed on to the governors of the federal states on 1 July 1948 in Frankfurt. This meeting in Frankfurt was anything but a conference, with presentations of various points

\footnotetext{
${ }^{2}$ K., Jaspers, Die Schuldfrage, Schneider, Heidelberg-Zürich 1946.

${ }^{3}$ M. Halbwachs, Les cadres sociaux de la mémoire, Presses Universitaires de France, Paris 1925.
} 
of view, followed by a discussion. It was rather an 'occurrence', when the first German representatives were handed very important decisions made by the allied powers without their knowledge. ${ }^{4}$ Democracy was to be imposed on the future representatives and the whole society.

Nine prime ministers of the states and two mayors of city-states (Bremen and Hamburg) obtained a political authorization in the form of a document, which launched a breakthrough on their way to sovereignty. The document recommended territorial reform, outlined the occupation status and, last but not least, authorized the local administration to sketch out a constitution. The effect of these works on the most important state document was accomplished in spring 1949, and the date of May 23 is considered as the beginning of the Federal Republic of Germany. The constitution, officially named 'Basic Law' ('Grundgesetz'), however, was of a makeshift character and, in spite of the usurpation involved in claiming to represent the rights of the entire German nation, it underlined the necessity for a public referendum to receive legitimacy in the eyes of the people. This is highlighted in the preamble ('acting in the name of those Germans whom the right to make a joint decision has been refused') and two articles of the 'Basic Law'.

The division of the nation into two separate political bodies created very awkward conditions to support a process of identity-building based on the classical conception, which assumes a deliberate and conscious activity of a larger community of people engaged in defining their distinctive features, values, and eventually self-determined structures with a firm intention to confirm their independence. It is identity that legitimizes the creation of a state and allows its citizens to consider themselves as members of the nation formed. The case of the Federal Republic of Germany varies from the classical model at all levels. According to Helmut Plessner's theory, Germany has always been a 'belated nation' ('verspätete Nation'), inapt at forming its national identity even in modern times, and even despite the fact that the Holy Roman Empire of the German Nation and several particular principalities had played major roles in European politics for centuries. ${ }^{6}$ As Plessner points out, the aggregate political changes in the $19^{\text {th }}$ and the beginning of the $20^{\text {th }}$ century - the downfall after Napoleon's conquest, the establishment afterwards of Prussian hegemony, a disastrous defeat

${ }^{4}$ Bundeszentrale für politische Bildung, Weichenstellungen für den Weststaat, 1 Sep 2008, $<$ http://www.bpb.de/geschichte/deutsche-geschichte/grundgesetz-und-parlamentarischer-rat s/39010/erste-schritte? $\mathrm{p}=1>$ [ access: 30.08 .2013$]$.

${ }^{5}$ Article 116 states that a German is understood as a person with German citizenship or a refugee from German territory in its shape in 1937, and their descendants. Article 146, though, states precisely the temporary character of the 'Basic Law': This Basic Law, which since the achievement of the unity and freedom of Germany applies to the entire German people, shall cease to apply on the day on which a constitution freely adopted by the German people takes effect.

${ }^{6}$ H. Plessner, Die verspätete Nation. Über die politische Verführbarkeit bürgerlichen Geistes, Kohlhammer, Stuttgart 1959. 
in World War I that led to inner instability and crisis - were not the appropriate conditions to render the German community a conscious, modern nation. The disgrace of the Third Reich, when all the ideas invoking national spirit were based not on patriotism and pride of belonging, but on aggressive nationalism and chauvinism, led to a real Zero Hour in every sense of the word, and in addition it was the foreign powers who were taking responsibility for the formation of a state with its conscious habitants.

Thus, the state-formation process after 1945 was everything but the initiative of a community aware of its uniqueness and bound by its affiliation to a German nation. The process was set in motion by the efforts of the Western powers, who confirmed the right of existence of a new, federal state. Democracy, rule of law, and individual and social rights were terms common to Western political systems, but totally unfamiliar to the vast majority of Germans, accustomed to a dictatorship. New models were implemented as a tool to replace the old ones; to replace a totalitarian form with a democratic one; to replace the violation of human-rights by laws with their firm guarantee. Thus, the first articles of the 'Basic Law' refer to such a guarantee of all basic rights, including very complex articles elaborating social and labour rights. The pragmatic character of the constitution marks a shift in the German consciousness - the shift from a 'nation' into a 'liberal community of equal rights'.

When it comes to the character of Germany's 'Basic Law', a theory of a new kind of patriotism was elaborated and it appears to have played a crucial role in the identity-creation process in the FRG, at least in its early years. The concept, usually called 'constitutional patriotism' was formulated by Dolf Sternberger in 1947, even before work was commenced on the constitution, although the expression 'Verfassungspatriotismus' was not used at that time. In his work 'Notion of Homeland ('Begriff des Vaterlands'), Sternberger clearly separates two different notions of homelands that are hardly translatable into English. The first German term - 'Heimat' - is used with regard to the homeland including the family house, surrounding landscapes, family life and stories, local rites and customs that firmly belong to the past and can never be reached again. Representations of a homeland defined in these terms may be discerned in the movie trends of the 1950s, i.e. the 'Heimatfilme', the role of which has already been mentioned. The second notion of homeland refers to 'Vaterland', i.e. a place dwelled in by a community in which one was born and raised, both a place and provenience. With respect to the notion of 'Vaterland', the constitution plays a significant replenishment role, guaranteeing its citizens particular rights and conditions in which to flourish. Sternberger illustrates his theory using examples from the past, when citizens felt intense bonds with the law order in their states. ${ }^{7}$ In Sternberger's opinion,

7 D. Sternberger, Der Begriff des Vaterlands, [in:] Verfassungspatriotismus, red. P. Haungs, Nr. 10, Insel, Frankfurt am Main 1990, p. 15. 
the Vaterland - a community of free citizens - fulfils itself in a political constitution. Their love towards their homeland is expressed not by an immense feeling of connection between them and the long history of the country, as this history cannot be altered. Much more love and attachment derives from the citizens' will to participate in the homeland's existence, provided that they are aware of the role of the constitution as the only means to achieve it.

For Sternberger, German history provided almost no reasons to establish a common culture based on the idea of constitutional attachment to the homeland. His conception was a reaction to the negative revaluation of the classical notions of patriotism - as territory, kinship or bonds of blood - that held sway both in the Weimar Republic and above all in the Third Reich. Sternberger argued: 'Vaterland is a republic that we create for each other. Vaterland is a constitution that we make alive. Vaterland is a liberty that we truly enjoy only when we support it on our own, when we use it and guard it. ${ }^{9}$ Later he further developed his concept when he proposed the idea of 'state friendship' in 1959, stressing that every citizen ought to be a friend of the constitution'. Finally, he elaborated on the concept again in 1979 , this time using the term 'Verfassungspatriotismus' for the first time.

The idea of 'constitutional patriotism' was revived later, during the dispute between historians in 1986. In the debate about the origins of national socialism, equating two totalitarianisms Jürgen Habermas, in his response to the notorious article of Ernst Notle ('The past that does not want to pass' - 'Die Vergangenheit, die nichtvergehen will') reaffirmed the concept of patriotism while taking into account the key role of the constitution. In his article 'A kind of indemnification' ('Eine Art der Schadenabwicklung') Habermas argued that the 'Basic Law' was a document which, due to its practical character, perfectly located the new German state in the geopolitical situation of the 1950s and tied it in with the Western system of values. ${ }^{10}$

The emergence of constitutional patriotism in the FRG took place simultaneously with the integration processes occurring in the Western Europe. From the very beginning, Germany was an active participant in and member of the integration initiatives. This was possible thanks to the establishment of a new German political culture that put supranational cooperation between democracies before the traditionally-viewed social affiliation of the state's citizens. Constitutional patriotism turned out to be a very advantageous phenomenon, capable of being used at the international level. The integration of Germany with the Western international structures should be reckoned as the third crucial element of the iden-

8 Ibidem, 31.

9 G.J. Wąsiewski, Koncepcja ,,patriotyzmu konstytucyjnego” Jürgena Habermasa. W kręgu poszukiwań modelu ustrojowego Unii Europejskiej, Adam Marszałek,Toruń 2011, p. 154.

${ }^{10}$ J. Habermas, Eine Art Schadensabwicklung, "Die Zeit", 11 Jul $1986<$ http://www.zeit. de/1986/29/eine-art-schadensabwicklung> [access: 26.09.2014]. 
tity-building process. European integration in political, economic and military alliances have today come to stand for a successful initiative based on ideas of peace and collaboration. And for Germany, the struggle to join these alliances was one of the key policy objectives of Adenauer's government, as it meant a guarantee of peace, security and prospects for a rapid economic development. The string of successes in domestic policy of the 1950s, i.e. the 'economic miracle' ('Wirtschaftswunder') and the birth of consumerism, followed by cultural resurgence, all took place at the same time as Germany's gaining independence and its joining the international organizations. Highlights in this course of action include the signing of the New York Declaration in 1951, which settled the framework of German independence, accession to the North Atlantic Treaty Organization in 1955, and its co-founding of both the European Community of Coal and Steel in 1951 and the European Economic Community in 1957. The icing on Adenauer's political cake was the signing of the Elysian Treaty with France in 1963, that reconciled both countries and initiated an immensely fruitful bilateral cooperation. Even though the Chancellor estranged a large part of the society with some off-putting manners, ${ }^{11}$ he entered into history as an eminent statesman and one of the Europe's modern fathers.

It should also be stressed that the FRG strongly supported the initiative of creating the European Defense Community, authored by the French prime minister Rene Pleven in 1950. After the FRG, France, Italy, the Netherlands, Belgium and Luxembourg signed the treaty, the German Bundestag put the motion to a vote in March 1953. It gained 224 voices in favour and 165 against, apparently meaning the motion passed. The opposition party SPD claimed, however, that the motion, in order to pass, required not an ordinary majority, but a qualified majority, and sent the issue to the Highest Constitutional Court to consider. The problem was unexpectedly resolved after the treaty was rejected in France - paradoxically, the country it derived from. The treaty was put up for ratification in the French National Assembly on 30 August 1954, and failed by a vote of 319 against, and 264 in favour. Although the plan suffered defeat, it confirmed the great attention that German political circles paid to such projects. The effort to belong to an international military organization was fulfilled in 1955, when Germany's access to North Atlantic Treaty Organization actually took place. The following years - revoking the Hallstein Doctrine and building relations with the Eastern Bloc countries during the era of Willy Brandt - bore fruit when Germany joined the United Nations Organizations in 1973, and then played an important role during the Conference for Security and Co-operation in Europe, which ended the same year with the signing of the Helsinki Act. During his visits to the Soviet

${ }^{11}$ Adenauer fell into the disfavor of German society when the so called 'Spiegel affair' came to light in 1962. What's more, despite his previous pledges not to remain in power at any price, he did not want to hand over the chair of Chancellor to another CDU-politician for a long time, i.e. until 1963, when he was replaced by Ludwig Erhard. 
Union, Poland, DRG, Czechoslovakia, and in Helsinki, Brandt acknowledged all European boundaries, including the Oder-Neisse-boundary, and forswore the use of violence or threats in international politics. In doing this, Brandt's declarations broadened the list of the essential values and objectives in German policy. The détente offered by Brandt's government proved that these declarations were not just empty words, but were put into practice. This not only enshrined Germany's position among other European countries, but also showed that Bonn would independently purse a policy based on these values in its relations with the Central and Eastern European states.

\section{European Identity - main characteristic points}

At the same time as the FRG became a widely acknowledged state, the first voices of European identity were raised in the Western community. While in its initial phases the process of European integration revolved around economic issues, the years following the two fuel crises in the 1970s, and the first extension of the European Economic Community in 1973, brought about a new debate over broadening the cooperation to include different areas. It was in the 1970s that the first document about common values was published. Although the Copenhagen Declaration of 1973 today seems rather obscure, it was an impulse in the discourse of abstract values of the community. What's more, its very title ('Declaration of European identity') gives the whole set of shared values a name, calling it 'identity', a very significant phenomenon. At the European Summit in Copenhagen in December 1973, the Heads of State or Government of the Member States of the already enlarged European Community affirmed their determination to introduce the concept of European identity into their common foreign relations. The objective of the declaration is formulated in the introduction, which reads as follows: 'The Nine Member Countries of the European Communities have decided that the time has come to draw up a document on the European Identity. This will enable them to achieve a better definition of their relations with other countries and of their responsibilities and the place which they occupy in world affairs'. ${ }^{12}$ It is further developed in item 5, which reads: 'International developments and the growing concentration of power and responsibility in the hands of a very small number of great powers mean that Europe must unite and speak increasingly with one voice if it wants to make itself heard and play its proper role in the world'. Other initial paragraphs also emphasize their disunity and their habit of 'selfishly defending misjudged interests' in the past, but then pledge to 'preserve the rich

${ }^{12}$ Declaration on European Identity (Copenhagen, 14 December 1973), <http://www.cvce.eu/ obj/declaration_on_european_identity_copenhagen_14_december_1973-en-02798dc9-9c69-4b7db2c9-f03a8db7da32.html> [access: 26.09.2014]. 
variety of their national cultures'. The first item of the declaration clearly enlists the most basic values the Member States commit themselves to defend - respect for human rights, representative democracy, needs of individuals, the rule of law and social justice. All the signatories highlight the originality of the community - all of the Members have a different cultural heritage and history, their own identity and interests, but are bound by their attachment to generally accepted principles.

Furthermore 'the Nine' viewed themselves as a community striving to promote their values and principles in relations with third countries, and to 'contribute to international progress, both through their relations with third countries and by adopting common positions wherever possible in international organizations, notably the United Nations and the specialized agencies'. Thus, the document is not only a declaration of common identity factors, but also an emancipation declaration of the power, or at least of the potential, the Nine possessed and wished to make use of. They were striving to strengthen their cohesion and be co-responsible for the entire external policy of Europe.

Many concepts of the Copenhagen summit were included and developed in the Fontainebleau Declaration of 1984. Here the word 'identity' is repeated once more in the context of a set of shared values: 'The European Council considers it essential that the Community should respond to the expectations of the people of Europe by adopting measures to strengthen and promote its identity and its image, both for its citizens and for the rest of the world ${ }^{13}{ }^{13}$ There is a characteristic feature included in this phrase that shows that 'identity' is juxtaposed with 'image' on the same semantic level. Based on the resolution of the Fontainebleau summit and the antecedent Copenhagen Declaration, it follows that the shared values are a factor the Community would take pride in, even boast about, in its relations with third countries.

The term 'identity' appears in other subsequent official acts and declarations as well. The reforming Single European Act of 1986, for instance, mentions it in paragraph 30 focusing on the common foreign policy. Passage 6 reads: 'The High Contracting Parties consider that closer co-operation on questions of European security would contribute in an essential way to the development of a European identity in external policy matters. They are ready to co-ordinate their positions more closely on the political and economic aspect of security ${ }^{14}$. As we can observe, identity in this context is determined solely by the security policy issue, whereas the common heritage or values are not mentioned at all. Notwithstanding

${ }^{13}$ European Council Meeting at Fontainebleau, $<$ http://www.european-council.europa.eu/media/849292/1984_june_-_fontainebleau_eng_.pdf> [access: 26.09.2014].

${ }^{14}$ Single European Act, "Official Journey of the European Communities", 30, 29 Jun 1987 $<$ http://eur-lex.europa.eu/LexUriServ/LexUriServ.do?uri=OJ:L:1987:169:FULL:EN:PDF> [access: 26.09.2014]. 
this anomaly, the Act contains other expressions indicating the existence of values such as 'work' or 'European idea' introduced by the economic integration of the 1950s that are named in the preamble.

The Treaty establishing the European Economic Community signed in Maastricht in 1992 gives a much more detailed account of these values, and 'identity' is to be found in the Treaty three times. In the preamble the parties declare themselves 'resolved to implement a common foreign and security policy including the eventual framing of a common defense policy, which might in time lead to a common defense, thereby reinforcing the European identity and its independence in order to promote peace, security and progress in Europe and in the world'. It is then repeated in Title 1 of the treaty, as among the objectives the Union shall set itself is: 'to assert its identity on the international scene, in particular through the implementation of a common foreign and security policy including the eventual framing of a common defense policy, which might in time lead to a common defense'. 'Identity' is repeated in the same context in the declaration about relations with the Western European Union (article 4 of the declaration, which forms a separate part of the treaty). It becomes clear that, above all, the concept of 'identity' is connected to issues of security and defense policy, whereas common values are rather included in the term 'cultural heritage' that according to Article 151 of the treaty should be preserved and safeguarded.

Even the Treaty of Lisbon amending the Treaty on European Union and the Treaty establishing the European Community from 2007 continues this tendency not to refer to European 'identity' directly, but instead to allude to it in the preamble, referring to the 'the cultural, religious and humanist inheritance of Europe, from which have developed the universal values of the inviolable and inalienable rights of the human person, freedom, democracy, equality and the rule of law' ${ }^{15}$. The term 'identity' is evoked only with reference to churches and other organizations, when the Parties commit themselves to respect their 'identity and special contribution' (Article 16c) by respecting 'the equality of Member States before the Treaties as well as their national identities, inherent in their fundamental structures, political and constitutional, inclusive of regional and local self-government' (Article 3a).

Based on the examples mentioned above, the European Union seems to be not willing to call its common values and heritage an 'identity', leaving the concept instead on the national level. The omission of this essential term obliterates some previous ambitions to directly express the meaning of 'identity', as presented for example in the Copenhagen Declaration. In addition, this narrowing trend appears to contradict the advanced process of further integration, as witnessed by EU enlargements, reforming the law, creating institutions responsible

${ }^{15}$ Treaty of Lisbon, "Official Journal of the European Union", 50, 17 Dec 2007, <http://eurlex.europa.eu/LexUriServ/LexUriServ.do?uri=OJ:C:2007:306:FULL:EN:PDF>. 
for common foreign and security policy or, in a nutshell, gaining power in international relations. Thus, an equation mark needs to be put between 'European identity' and 'European heritage and values', especially considering the fact that the European Union supports common culture by financing various programs and initiatives in the matter. ${ }^{16}$ This failure to use the term 'identity', or to invoke it except in relation to some limited agendas (such as security policy) might result from a reluctance to generalize the expression which is typically reserved for national identities. This may indicate that 'identity' is thought of only in a national context, whereas common values and heritage, despite being the issues the Union emphasizes and protects so firmly, are not considered as factors of a 'common identity'.

Another factor, although not stemming directly from the content of the treaties and declarations that characterize European identity, is the great number of official documents that form its jurisprudence. 'Common heritage and values' are included in the texts of various treaties, acts, declarations, and the practice of codification of law also becomes a part of this heritage. Acceptance of the EU's legal legacy is required when any country decides to join the European Union - each accession treaty demands this expressis verbis. The institutional face of the Union - the great number of political bodies guarding the values set out in the EU's legal legacy - can be viewed as a part of European 'identity', very noticeable especially in the Union's relations with other subjects.

\section{German identity - European identity. Inspiring resemblances}

In comparing the two processes of identity-forming in Germany and the European Union, some distinctive analogies are easily observable. Both in Germany and in the Union the process is not based on a grass roots initiative proposed by the people/citizens, but is an institutional movement, a top-down man oeuvre conducted by the political elites through the implementation of a legal order. The acknowledgement of a social state and a state governed by the rule of law, guaranteeing equal rights to all its citizens, was the initial condition for forming a new, modern German state. These values, formed and then guarded by Germany's 'Basic Law', embodied the German image of breaking off the ties with the former

${ }^{16}$ In this context various programs may be named, e.g. Raphael (protection of European heritage), Arianne (promoting literature). The European Union also supports culture using both central financial programs (Framework Program Culture 2000 and its 'successor' Program Culture 20072013 and Program Media Plus or Program Europe for the Citizens) as well as the structural funds that are implemented in each of the member states. Other European programs worth mentioning are European Capital of Culture, European Month of Culture and the Europa nostra. 
political regime, and opened Germany's way to integration with the Western communities. The European Union has developed very similar mechanisms to guarantee common rights and values in all of the Member States. For this reason the term 'constitutional patriotism' can undoubtedly be applied and used also in the European discourse. The theories proposed by Dolf Sternberger and later developed by Jürgen Habermas easily adapt themselves to the European context. Therefore, the constitutional tradition may be considered as a crucial factor in the identity-building process of both subjects.

In the same way as the national law in any country needs to be reformed from time to time to reflect changes in the social and political life, the law of the European Union also submits to amendments by introducing new, reforming treaties. This tendency confirms another feature of every identity concerned with a national, abstract context, with its fluent and incessant nature. Debates about national heritage, history and culture are present in the lives of every country and often change its image, and with it citizen's consciousness and identity. Germany is a very distinct example - for many years following reunification in 1990 new historical debates rapidly changed the national identity. The role of particular groups in the Third Reich crimes, the singularity of holocaust amongst other genocides, the commemoration of various persecuted groups in the centre of Berlin, and compensation for persons who once had been conscripted into hard labour are only a few examples that contribute to the development of the German identity discourse. The continuing debates about being proud of belonging to the German state show that the German process is absolutely unique and that identity may be influenced not only by politicians or intellectuals, but also by sports events like World Football Championship in 2006. ${ }^{17}$

Likewise, the European Union experiences solemn debates and disputes about its identity, embodiment of tradition, and its role in future global challenges. The failures that the Union has recently suffered - the rejection of the Constitutional Treaty in the French referendum in 2004, or the negative outcome in the first Irish referendum that would have allowed for ratification of Lisbon Treaty in 2008 - unveiled a deep rift between the intentions of the EU bureaucrats and the consciousness or interests of European societies. Publically expressed dissatisfaction, which became especially evident in several southern countries of the Union in the face of the financial crisis, indicate a lack of communication between the European elites and the European societies. European identity is not a finished process, as is particularly visible in the rising popularity of some

${ }^{17}$ During the Championship, every victory by the Germany football representation was followed by various acts of effusive euphoria. The national anthem was sung in public places, almost every car had a miniature national flag attached to the hood, and people loudly expressed their pride in being German, without shame. See e.g. J. Leinemann, WM-Patriotismus: Ein glückliches Volk, "Spiegel Online“, Jahreskronik 1 (2006), <http://www.spiegel.de/jahreschronik/a-452551.html>. 
euro-sceptic parties or groups in various countries that contest the EU immigration law, some elements of social justice principles, or the unlimited tolerance towards non-European inhabitants.

Coming up with a catalogue of the values defining what is typically European and what does not belong to the European legacy, tradition and culture seems to be a very debatable matter. While respect for human rights, democratic systems, or living in peace appear to be obvious values that have been elaborated on for decades and are now firmly entrenched in the European legacy, the general shape, including traditional roots and origins of Europe, particularly in the context of different current problems like mass immigration, further EU-expansion, or the financial crisis, differs depending on the points of view in different countries. The secularization tendency in Europe, for example, which has been evident for at least two decades, meets with the opposition of the clergy in many member states and in conservative groups as well. Even though the role of the ties bonding Europe with its Jewish-Christian tradition were indisputable for the modern Europe's founding fathers, their standpoints are rarely evoked nowadays. The fact that the fathers of the European integration looked up to the Christian roots of the continent has been pointed out by the Catholic Church, which pays great attention to the differences between the former and the contemporary views on religion and secularism in Europe. Joseph Ratzinger, for instance, in his speech in Berlin in 2000, accentuated: 'We are standing before a question: What will be next? In time of rapid changes - is there an European identity with a future and with us connected to it? For the creators of European identity, after the destruction of World War II - Adenauer, Schumann, de Gasperi - it was obvious that there was a solid base for it; the European identity is a part of the Christian heritage of our continent'. ${ }^{18}$ Struggles over the presence of crosses in public places are an example of the loosening of the Christian ties, and even the most drastic or ludicrous propositions, such as the one that Christmas trees should be banned from public areas, find many supporters. On the other hand, the growing rate of Muslim immigration is considered by many as a jeopardy to European tradition and causes apprehension about the future. The upcoming decades will surely verify just how justified these fears are, and in what direction the secularization wave goes.

Nevertheless, if the European Union eventually resigns from Christianity as an indisputably essential factor of its common heritage, and focuses solely on a catalogue of values and its legal legacy, it will become a very bizarre and unquestionably incomplete community. History, which includes not just the latest developments and breakthroughs but also the more distant ages, is still an essential factor in the identity-building process, regardless of the state where it takes

18 J. Joofe, Deutsch und stolz, "Die Zeit", 22 Mar 2001, <http://www.zeit.de/2001/13/ Deutsch_und_stolz Lohse> [access: 25.09.2014]. 
place. Of course, the differing views on many issues in all the Member States do not facilitate the process of establishing a coherent identity in the Union, but neither do they render it impossible. It is worthwhile to come back to the German example once again. Numerous debates after 1990 revealed large disparities in opinions on crucial issues concerning the German identity. No other European country has experienced so many audible and ground-breaking disputes about the role of the past in contemporary life and the attitude toward patriotism as Germany, where the sense of 'patriotism' has always been overshadowed by the fear of 'nationalism'. When Laurentz Meyer, the general secretary of CDU-party, publically confessed he was proud of being German, he probably was not aware of the uproar his confession would cause. His opponent, Jürgen Trittin, the Federal Minister of the Environment, Nature Conservation and Nuclear Safety, instantly reproached him and accused him of having the 'mentality of a skinhead'. Even the Federal President, Johannes Rau, joined the discussion and admitted that one can be happy or glad of being a German, but not proud, for one cannot be proud of others' achievements. ${ }^{19}$ Now, several years after that debate, a patriotic confession is no longer a reason to feel fear of ostracism. The football championship of 2006 contributed to this state to a large extent, but it was obviously not the sole factor redefining the national identity. Nowadays, Germans take pride in keeping up their good name in the production sector, being satisfied that the mark 'made in Germany' is a synonym of high quality and reliability. They also advertise Germany's cultural legacy, and various countries find it attractive to promote German literature, film or events in their own institutions. Therefore, the German model may be easily regarded as exemplary and could be taken under consideration in the European debates about the continent's identity.

\section{Recapitulation and prospects}

The European model of integration and defining identity was once an objective Germany chose to follow and draw on. Germany incorporated the main concepts of the international law legacy and implemented them in its own legal and public order. The connection it established with Western structures, followed by taking some responsibility for leading them, confirmed the role Germany would play in the following years in international relations. The promotion of human rights, emphasis on dialogue, relinquishment of threats and its bridge-building policy with the East-European countries all turned out to be crucial for the international image of the FRG and the process of creating a new, modern national identity.

${ }^{19}$ E., Ich bin gerne Deutsch, weil..., "Frankfurter Allgemeine Zeitung, 20 Mar 2001, <http:// www.faz.net/aktuell/politik/patriotismusstreit-ich-bin-gerne-deutscher-weil-115759.html> [access: 25.09.2014]. 
Nowadays, the German discourse on coming to terms with the past and its equilibrium-focused policy that relies on respecting everyone's rights and opinions, together with its success in elaborating a quite coherent identity and its appropriate perception in society, may be seen as an optimistic impulse and scenario for the European community. The German example shows that an identity can be formed in spite of a difficult past and its ignoble experiences.

At this point, some opinions should be stressed in summary. First, the European Union ought to remind itself of its historical roots without being afraid to call a spade a spade - in this case it should highlight the Christian legacy of the continent, which is undeniably visible even in the architecture of the European towns and cities. Evoking this legacy is not necessarily a peril for the rights of the members of other religious groups or people who declare themselves atheists. But highlighting secularism at any price will probably lead to a semantic gap in the notion of identity, and thereby become an obstacle to its comprehension. Moreover, the community should make more efforts to emphasize the term 'identity' in its discourse. The concept, once mentioned in the Declaration of Copenhagen in 1973, has been gradually losing its importance and existence, being replaced by other, less concrete terms like 'values' or 'heritage'. Perhaps in the face of new challenges of EU the term should be reconsidered once again. 